Jamille Gregório Dombrowski ${ }^{1}$

Ricardo Ataíde ${ }^{1}$

Paola Marchesini ${ }^{1}$

Rodrigo Medeiros de Souza ${ }^{1}$

Cláudio Romero Farias Marinho ${ }^{1}$

${ }^{1}$ Departamento de Parasitologia, Instituto de Ciências Biomédicas, Universidade de São Paulo. Av. Prof. Lineu Prestes 1374/131. Laboratório 40, Butantã. 05508-900 São Paulo SP Brasil. milledombrowski@usp.br

\section{Effectiveness of the Live Births Information System in the Far-Western Brazilian Amazon}

\author{
Eficácia do Sistema de Informação de Nascidos Vivos \\ na Amazônia Extremo-Ocidental Brasileira
}

Abstract The Live Birth Information System (SINASC) was implemented in 1990 for the purpose of providing information about the live-birth characteristics for the establishment of specific health indicators. This work evaluates the information quality of SINASC in relation to its data completeness and coverage for five municipalities from the State of Acre from 2005 to 2010. Lack of information (not filled out or stated as "unknown") was estimated for each variable. Coverage was estimated comparing the Civil Register office statistics in accordance with the mother's municipality of residence. An increase in incompleteness of the majority of variables was observed, and also a decrease in coverage between 2005 and 2010 in these municipalities. These findings do not tally with results from the majority of studies that use SINASC as a data source. The results of this work highlight the relevance of continuous capacity building and the incentive for accurate and complete data inclusion, as well as awareness of the importance of SINASC for public health policies.

Key words Information systems, Live births, Birth certificates
Resumo O Sistema de Informação de Nascidos Vivos (SINASC) foi implantado no ano de 1990 com o objetivo de fornecer dados sobre as características de nascidos vivos para o estabelecimento de indicadores de saúde específicos. Objetivo: $O$ presente trabalho avalia a qualidade da informação do SINASC quanto à incompletude dos seus dados e da cobertura para cinco municípios do estado do Acre nos anos de 2005 e 2010. Métodos: Foi calculada a incompletude (definida como dados em branco/ignorado) de cada variável, assim como a cobertura desse sistema através da comparação com as estatísticas do Registro Civil, segundo município de residência da mãe. Resultados: Observou-se um aumento da incompletude da maioria das variáveis e uma diminuição da cobertura de 2005 para 2010 no conjunto dos municípios avaliados, destoando dos resultados obtidos na maioria dos estudos que utilizam o SINASC como fonte de dados. Conclusões: Os resultados deste trabalho apontam para a importância da contínua capacitação e também para o incentivo ao preenchimento dos dados de forma correta e completa, bem como a conscientização da importância do SINASC para as politicas públicas de saúde.

Palavras-chave Sistemas de informação, Nascidos vivos, Declaração de Nascimento 


\section{Introduction}

In 1990, the Brazilian Ministry of Health created and implemented the Live Births Information System (SINASC), based on the Live Birth Notification (DNV in Portuguese). The main goal of this system is to provide information about the live-birth characteristics that are essential for the establishment of specific health indicators ${ }^{1}$. The SINASC has unique characteristics, not present in many countries around the world, like national coverage and an online repository for sending and collecting data ${ }^{2}$. All the flow, routines and protocols regarding the filling out and processing of the data are defined by the Ministry of Health and are available in a manual on how to fill the $\mathrm{DNV}^{1}$, as well as in the SINASC procedures manual $^{3}$.

The DNV is a nationwide standard document of compulsory use in Brazil. This document is printed in a unique numerical sequence and in groups of three equal forms. The issuance and distribution of these forms to the State Health Secretaries is a responsibility only of the Ministry of Health ${ }^{1}$. Only the health professionals and midwives (when recognized and linked to health units) that are responsible for the delivery or the care of the newborn can fill out the DNV. For data entry into the DNV, priority should be given to the information provided by the mother and the health professionals who attended the birth, as well as information contained in all the relevant documents, such as medical charts and other important notes ${ }^{1}$.

In addition to the number of births, the SINASC holds information on the epidemiological characteristics of the mother, the pregnancy, the delivery and the newborn ${ }^{4}$.This makes it a very important source of information on health, demographic and epidemiologic indicators often used to guide decision-making within the municipalities ${ }^{5-7}$. Furthermore, it is an important source for estimation of live births with low birth weight, mothers with four or more antenatal care visits, caesarian deliveries, place of delivery, congenital diseases and other characteristics ${ }^{4}$. For this it is necessary for the SINASC to have a good quality of data coverage, filling, typing, coding and correction. The quality of these vital statistics can be evaluated at various stages of the process, from data collection, through the percentage of blank or "ignored" information, to the accuracy and consistency of these data ${ }^{8}$.

Implementation of the SINASC has been done in a decentralized manner. Periodic evalu- ations are necessary, at both the municipal and state levels, to assess the ability of obtaining information on births - in quantitative and qualitative terms - as well as on other demographic and epidemiological data from the DNV 9 . This analysis is necessary and important in order to understand the system's limitations and shortcomings, in addition to ensure that the indicators estimated will reflect the actual profile of the population $^{10}$.

The evaluation of the degree of coverage of a database can be performed through comparison with another database considered reliable ${ }^{11}$. This coverage is related to the ability of obtaining all the events that happened in a particular region in a defined period of time ${ }^{12}$. According to Paiva et al. ${ }^{13}$, only one study in northern Brazil used the SINASC as a data source. This fact highlights the need for more studies covering this region to assess the quality of the SINASC.

Due to the geographic and demographic characteristics of the Vale Jurua region, in the State of Acre, its municipalities use the four flows of the DNV defined in the Ordinance $n^{\circ}$ 116 of February 11, $2009^{14}$ (Figure 1). So, the objective of this study is to analyze the SINASC in the Far-Western Brazilian Amazon, investigating whether there was a change, between 2005 and 2010 , regarding the coverage and incompleteness of data in five municipalities within the State of Acre. These five municipalities are called the Alto Juruá region: Cruzeiro do Sul, Mâncio Lima, Marechal Thaumaturgo, Porto Walter and Rodrigues Alves.

\section{Methods}

The data analyzed correspond to the DNV recorded in the SINASC from five municipalities in the Vale do Juruá region: Cruzeiro do Sul, Mâncio Lima, Marechal Thaumaturgo, Porto Walter and Rodrigues Alves in the years 2005 (3,744 births) and 2010 (3,275 births). 2010 was the last year available from the Health Surveillance Department until the completion of this study.

The SINASC database is available on the website of the Department of Information and Computing from the Health Unique System (Datasus) $)^{15}$. For comparison and analysis of the coverage of the SINASC, data from the Civil Registry of the Brazilian Institute of Geography and Statistics $(\mathrm{IBGE})^{16}$. The inclusion criterion for both systems was the municipality of residence of the mother. 

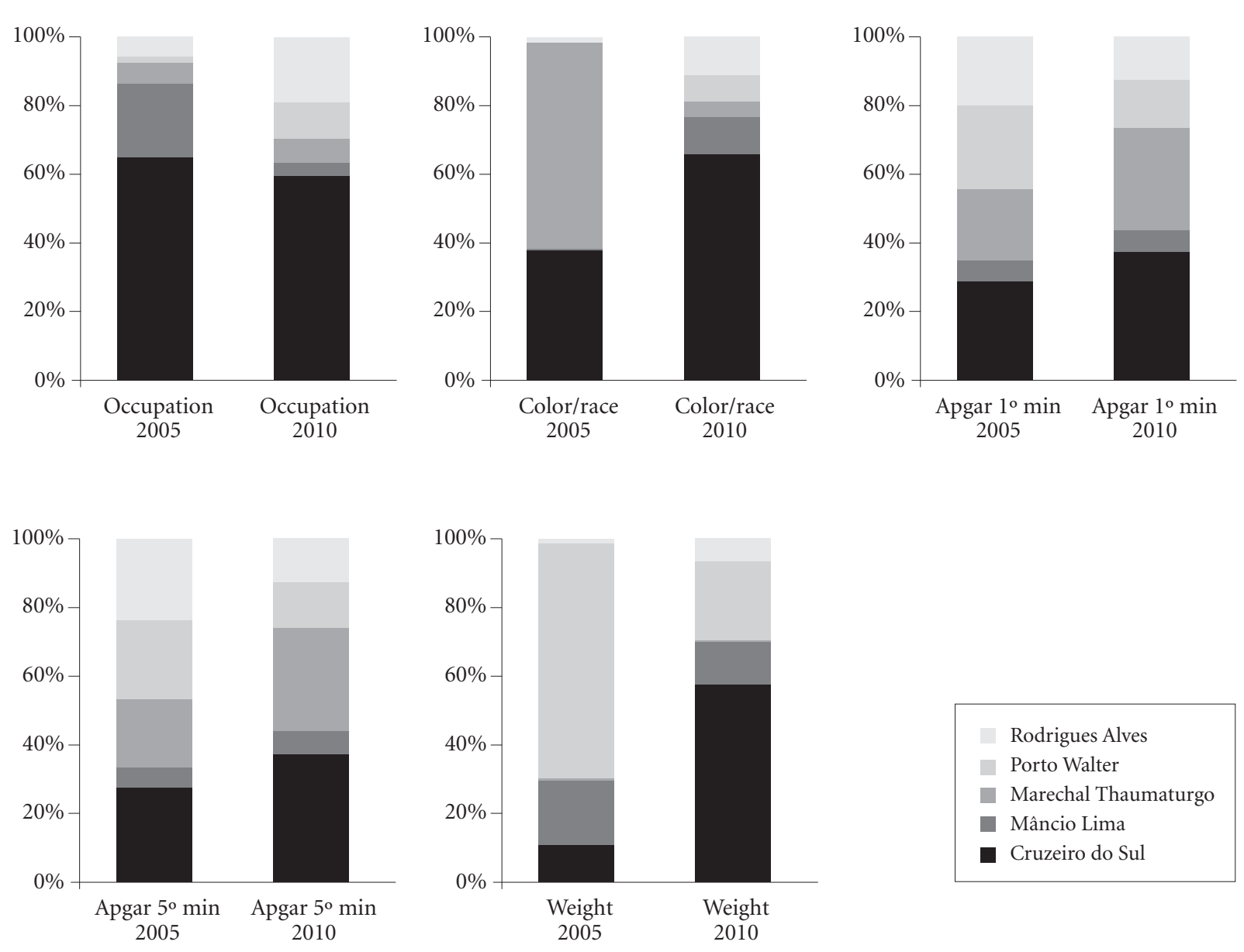

Rodrigues Alves

Porto Walter

- Marechal Thaumaturgo

Mâncio Lima

- Cruzeiro do Sul

Figure 1. Analysis of the proportion of "not declared" from all the variables classified as fair, bad or very bad; stratified by municipality.

Source: SINASC. Percentages represent the incompleteness attributed to each municipality in the Alto do Juruá region.

From all the variables available for tabulation (Chart 1), we have chosen to analyze maternal variables (age, marital status, education, occupation), pregnancy and delivery variables (place of birth, length of gestation, type of pregnancy, type of delivery and number of prenatal visits) and newborn variables (sex, race/colour, Apgar scores at 1 and 5 minutes, weight and congenital anomalies).

The coverage analysis was performed by comparing the data from the SINASC with that from the Civil Registry from 2005 and 2010. Statistics from the Civil Registry are used by the Federal Government to count the number of births, and despite the limitations already discussed by other authors ${ }^{10}$, are very useful for comparison. We measured the quantitative relationship between the live births reported in the SINASC and the ones registered in the Civil Registry, reflecting the coverage of the information system (see calculation method below). Results above 100 indicate that data from the Civil Registry were lower than the data from the SINASC records; a value below 100 indicates the reverse. A scale was defined to classify the degree of coverage of the SINASC: excellent (equal to or greater than 100), good ( 85 to less than 100), fair (70 to less than 85 ) and poor (less than 70).

Coverage $=$ (Number of SINASC certificates by year and mother's place of residence)/(Number of civil registry by year and mother's place of residence) $\times 100$ 


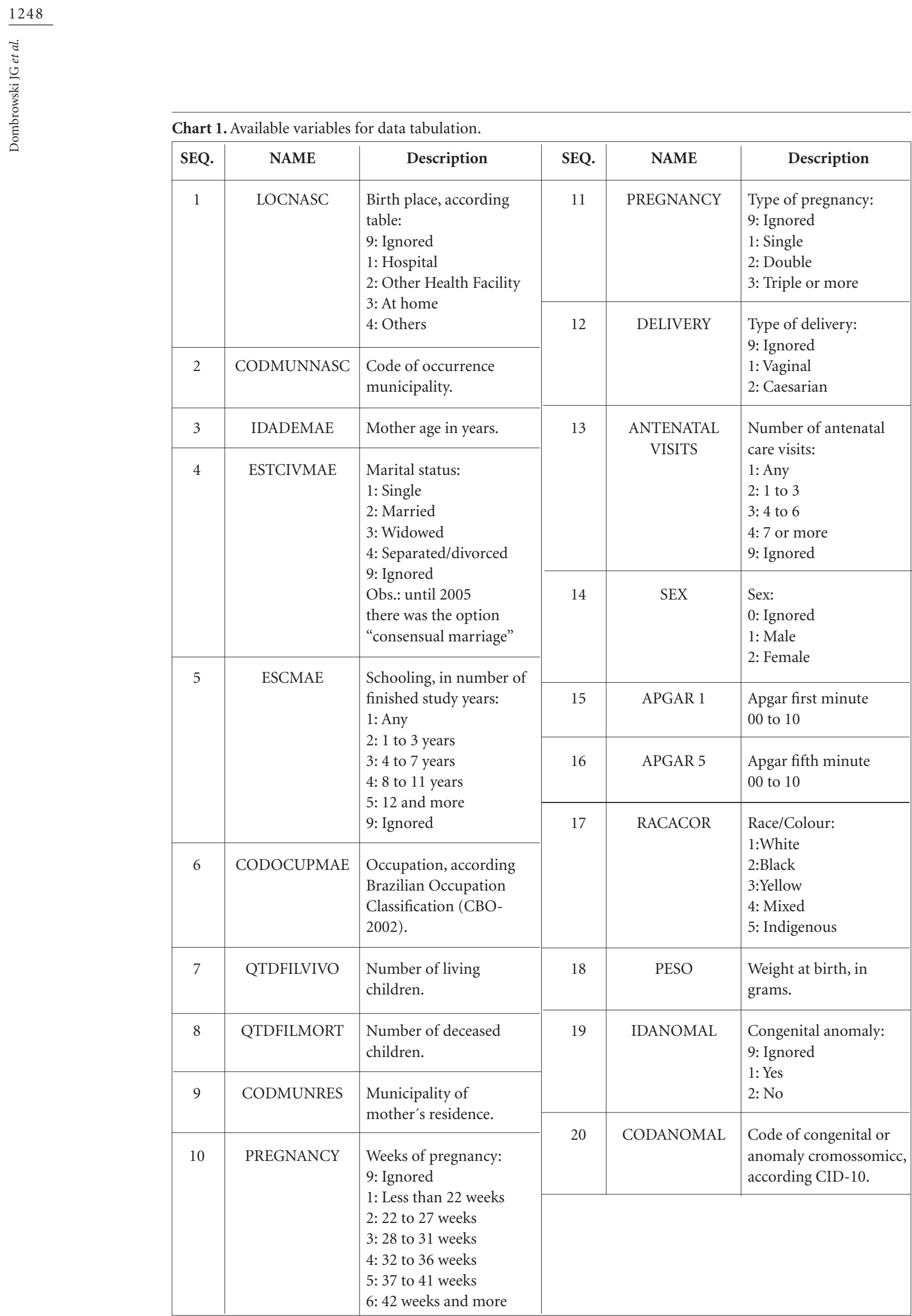


We have assigned a value of "not declared" to all the values in the database that were marked as "ignored" plus "unfilled" (blank). To assess the quality of the SINASC data concerning incompleteness, we used the grading scale created by Romero and Cunha ${ }^{17}$ : excellent (less than 5\%), good (5 to $10 \%$ ), regular/fair (10 to $20 \%$ ), poor (20 to $50 \%)$ and very poor (50\% or more).

Data quality from the SINASC, regarding its incompleteness in the Alto do Juruá region, was first analyzed for the group of five municipalities together, through absolute and relative frequency of "not declared" for each year and variable. Then, the variables that showed percentages of "not declared" classified as fair, poor or very poor, in both years, were selected for review at the municipal level in a stratified manner toevaluate the profile of each city.

Data were analyzed using STATA ${ }^{\circledR}$ version 9.2, using the chi-square test to identify whether changes in the proportions were significant.

\section{Results}

\section{Coverage}

Analysis of the coverage of the SINASC, relative to the Civil Registry, showed that there was a decrease in four of the five municipalities, demonstrating under reporting in this information system (Table 1). As can be observed in Table 1, in 2005 only the municipality of Marechal
Thaumaturgo was classified as having regular/fair coverage $(74.8 \%)$. All the other municipalities analyzed had excellent or good coverage, ranking the SINASC coverage in the Alto do Juruá region as excellent (109.4\%) for 2005. However, Vale do Juruá's coverage in 2010 has been classified as good (86.6\%) only because of Rodrigues Alves municipality had an excellent coverage (112.2\%) while the others were good or regular/fair.

In order to understand if the reduction in coverage from the SINASC was a local phenomenon, we analyzed data from Acre State, the North region of Brazil. We observed that, from 2005 to 2010, there was a general reduction of the coverage of the SINASC relative to the Civil Registry, which was more pronounced in Acre state, decreasing from $116.6 \%$ in 2005 to $93.8 \%$ in 2010 (Table 1).

\section{Incompleteness}

Table 2 shows the percentage of "not declared" from the SINASC variables analyzed for the Alto do Juruá region. In general, we could observe an increase in incompleteness for most variables from 2005 to 2010. Maternal variables, with the exception of age, ranged between good and regular, with an emphasis on occupation variable that has the most significant increase of "not declared", from $1.82 \%$ in 2005 to $16.73 \%$ in 2010 ( $p<0,0001)$. Regarding variables related to pregnancy and delivery, they all showed an increase in incompleteness in 2010 relative to 2005, with

Table 1. Number of live births by source of information, year of registration and the ratio of coverage between 2005 and 2010.

\begin{tabular}{|c|c|c|c|c|c|c|}
\hline \multirow[b]{2}{*}{ Place } & \multicolumn{2}{|r|}{2005} & \multirow[b]{2}{*}{$\begin{array}{c}\text { Ratio } \\
(1 / 2)(\%)\end{array}$} & \multicolumn{2}{|c|}{2010} & \multirow[b]{2}{*}{$\begin{array}{r}\text { Ratio } \\
(3 / 4)(\%)\end{array}$} \\
\hline & $\begin{array}{l}\text { SINASC } \\
\text { (1) }\end{array}$ & $\begin{array}{c}\text { Civil } \\
\text { Registry (2) }\end{array}$ & & $\begin{array}{l}\text { SINASC } \\
(3)\end{array}$ & $\begin{array}{c}\text { Civil } \\
\text { Registry (4) }\end{array}$ & \\
\hline \multicolumn{7}{|l|}{ Municipalities of Juruá region } \\
\hline Cruzeiro do Sul & 2,112 & 1,665 & 126.8 & 1,687 & 2,097 & 80.4 \\
\hline Mâncio Lima & 395 & 431 & 91.6 & 405 & 454 & 89.2 \\
\hline Marechal Thaumaturgo & 306 & 409 & 74.8 & 399 & 492 & 81.0 \\
\hline Porto Walter & 399 & 304 & 131.2 & 334 & 336 & 99.4 \\
\hline Rodrigues Alves & 532 & 612 & 86.9 & 450 & 401 & 112.2 \\
\hline Juruá region & 3,744 & 3,421 & 109.4 & 3,275 & 3,780 & 86.6 \\
\hline Acre & 17.482 & 14.998 & 116.6 & 16.495 & 17.584 & 93.8 \\
\hline Northern region & 314.858 & 254.115 & 123.9 & 306.422 & 262.175 & 116.9 \\
\hline Brazil & $3,035.096$ & $2,874.753$ & 105,6 & $2,861.868$ & $2,747.373$ & 104,2 \\
\hline
\end{tabular}

Sources: SINASC (raw data) and IBGE (www.ibge.gov.br). Classification scale: Excellent $\geq 100 \%$; good $85 \%$ to $100 \%$; fair $70 \%$ to $85 \%$; bad $<70 \%$. 
Table 2. Absolute and relative frequency of "not declared" in the SINASC for all the variables evaluated. Alto do Juruá region - 2005 and 2010.

\begin{tabular}{|c|c|c|c|c|c|}
\hline \multirow[b]{2}{*}{ Variables } & \multicolumn{2}{|c|}{$2005[$ N 3744] } & \multicolumn{2}{|c|}{2010 [N 3275] } & \multirow{2}{*}{$\begin{array}{c}\chi^{2} \\
\mathbf{p}(\text { value })\end{array}$} \\
\hline & $\mathbf{n}$ & $\%$ & $\mathbf{n}$ & $\%$ & \\
\hline \multicolumn{6}{|l|}{ Mother } \\
\hline Age & 11 & 0.29 & 0 & - & 0.002 \\
\hline Marital Status & 52 & 1.38 & 166 & 5.07 & $<0.0001$ \\
\hline Schooling & 63 & 1.68 & 137 & 4.18 & $<0.0001$ \\
\hline Occupation & 68 & 1.82 & 548 & 16.73 & $<0.0001$ \\
\hline \multicolumn{6}{|l|}{ Pregnancy and delivery } \\
\hline Place of birth & 0 & - & 1 & 0.03 & 0.285 \\
\hline Length of pregnancy & 8 & 0.21 & 294 & 8.97 & $<0.0001$ \\
\hline Type of pregnancy & 4 & 0.11 & 53 & 1.62 & $<0.0001$ \\
\hline Type of delivery & 7 & 0.18 & 36 & 1.10 & $<0.0001$ \\
\hline Number of antenatal care visits & 67 & 1.79 & 67 & 2.04 & 0.443 \\
\hline \multicolumn{6}{|l|}{ Newborn } \\
\hline Sex & 10 & 0.27 & 0 & - & 0.003 \\
\hline Race/Colour & 422 & 11.27 & 838 & 25.59 & $<0.0001$ \\
\hline Apgar $1^{\circ}$ minute & 1,153 & 30.79 & 870 & 26.56 & 0.004 \\
\hline Apgar $5^{\circ}$ minute & 1,219 & 32.56 & 869 & 26.53 & $<0.0001$ \\
\hline Weight & 366 & 9.78 & 414 & 12.64 & 0.001 \\
\hline Congenital anomalies & 123 & 3.28 & 229 & 7.00 & $<0.0001$ \\
\hline
\end{tabular}

Source: SINASC (raw data). Classification Scale: Excellent < 5\%; good 5\% to $10 \%$; fair $10 \%$ to $20 \%$; bad $20 \%$ to $50 \%$; very bad $>50 \%$. $\mathrm{N}$ is the total number of registered births. $\mathrm{n}$ is the absolute number of incompleteness. Percentage of incompleteness of variables (\%). Qui-quadrado test $(\chi 2)$. In bold the values are classified as fair, bad or very bad.

that increase being higher for the variable length of pregnancy, which increased from $0.21 \%$ to $8.97 \%(p<0,0001)$. All these variables remained between the quality levels of excellent and good. Variables related to the newborn showed a greater variation, ranging from excellent to poor. The variables race/colour, Apgar score at 1 minute, Apgar score at 5 minutes and weight showed the highest levels of "not declared" in 2005 and 2010, although the variables Apgar score at 1 minute and Apgar score at 5 minutes showed a very small reduction from the year 2005 to the year 2010 . No variable was classified as having very bad quality (Table 2).

For the stratified analysis, five variables that had a rating of either fair, poor or very poor were selected: occupation, race/colour, Apgar score at 1 minute, Apgar score at 5 minutes and weight. For the variable occupation, there was an increase in "not declared" in the municipalities of Rodrigues Alves and Porto Walter, while for Mâncio Lima and Cruzeiro do Sul there was a reduction. For the variable race/colour, there was an increase in the number of "not declared" in all municipalities except Porto Walter. The variables Apgar score at 1 minute and Apgar score at 5 minutes behaved similarly, with an increase of "not declared" in the municipalities of Marechal Thaumaturgo and Cruzeiro do Sul and a reduction in the municipalities of Rodrigues Alves and Porto Walter. The variable weight showed an increase of "not declared" in Cruzeiro do Sul and a reduction in Porto Walter (Figure 2).

\section{Discussion}

The results of this study show a decrease in coverage of the SINASC, relative to the Civil Registry, in the Alto do Juruá region from the year 2005 to 2010, as well as an increase in the percentage of incompleteness in the SINASC data in that same period. Like in Brazil, documents similar to the DNV are also in use in the United States and in many European countries, where they are called birth certificates and live births notifications, respectively ${ }^{2,18}$. They are widely used to monitor demographic and clinical characteristics ${ }^{18}$, and are also used as a data source for epidemiological surveillance programmes ${ }^{2}$. The SINAS Chas characteristics that are of the utmost importance for monitoring maternal and child health status, such as nationwide coverage, availability of disaggregated information, and a digital and standardized system. 


\begin{tabular}{|c|c|c|}
\hline \multicolumn{3}{|c|}{$\begin{array}{l}\text { FLOW 1: Health worker who assisted the hospital birth } \\
\text { (fill the } 3 \text {-way) }\end{array}$} \\
\hline 1st copy & 2nd copy & 3rd copy \\
\hline $\begin{array}{l}\text { Responsible file in Health } \\
\text { Establishments }\end{array}$ & Parent or legal guardian & $\begin{array}{l}\text { Responsible file in Health } \\
\text { Establishments }\end{array}$ \\
\hline $\begin{array}{l}\text { Until collected by staff of the } \\
\text { Municipal Health }\end{array}$ & $\begin{array}{c}\text { Used in obtaining the birth } \\
\text { certificate issued } \\
\text { by the Civil Registry }\end{array}$ & $\begin{array}{l}\text { Kept in the mother's } \\
\text { medical record }\end{array}$ \\
\hline
\end{tabular}

\begin{tabular}{|c|c|c|}
\hline \multicolumn{3}{|c|}{$\begin{array}{l}\text { FLOW 2: Health worker or traditional midwife assisted home birth } \\
\text { (fill the 3-way) }\end{array}$} \\
\hline 1st copy & 2nd copy & 3rd copy \\
\hline $\begin{array}{l}\text { Person who assisted } \\
\text { the delivery }\end{array}$ & Parent or legal guardian & Parent or legal guardian \\
\hline $\begin{array}{c}\text { To be forwarded to the Municipal } \\
\text { health Secretariat } \\
\text { or the Indigenous Health }\end{array}$ & $\begin{array}{l}\text { Used in obtaining the birth } \\
\text { certificate issued } \\
\text { by the Civil Registry }\end{array}$ & $\begin{array}{l}\text { To be presented } \\
\text { at the first appointment } \\
\text { at the Health Unit }\end{array}$ \\
\hline
\end{tabular}

\begin{tabular}{|c|c|c|c|}
\hline 1st copy & $\begin{array}{c}\text { FLOW 3: Homebirth unassisted Official Registry } \\
\text { (fill the 3-way) } \\
\text { 2nd copy } \\
\text { Official registry }\end{array}$ & Official registry \\
\hline $\begin{array}{c}\text { Kept in the Registry until } \\
\text { collected by staff of the } \\
\text { Municipal Health Secretariat }\end{array}$ & $\begin{array}{c}\text { To be kept in the Registry } \\
\text { after the issuance } \\
\text { of Birth Certificate }\end{array}$ & $\begin{array}{c}\text { To be presented } \\
\text { at the first appointment } \\
\text { at the Health Unit }\end{array}$ \\
\hline
\end{tabular}

\begin{tabular}{|c|c|c|}
\hline \multicolumn{3}{|c|}{$\begin{array}{l}\text { FLOW 4: Health worker or traditional midwife assisted home birth indigenous } \\
\text { (fill the 3-way) }\end{array}$} \\
\hline 1st copy & 2nd copy & 3rd copy \\
\hline Person assisted the delivery & Parent or legal guardian & Parent or legal guardian \\
\hline $\begin{array}{l}\text { To be forwarded to the Special } \\
\text { Indigenous Sanitary District }\end{array}$ & $\begin{array}{l}\text { Used in obtaining } \\
\text { the birth certificate issued } \\
\text { by the Civil Registry }\end{array}$ & $\begin{array}{l}\text { To be presented } \\
\text { at the first appointment } \\
\text { at the Health Unit }\end{array}$ \\
\hline
\end{tabular}

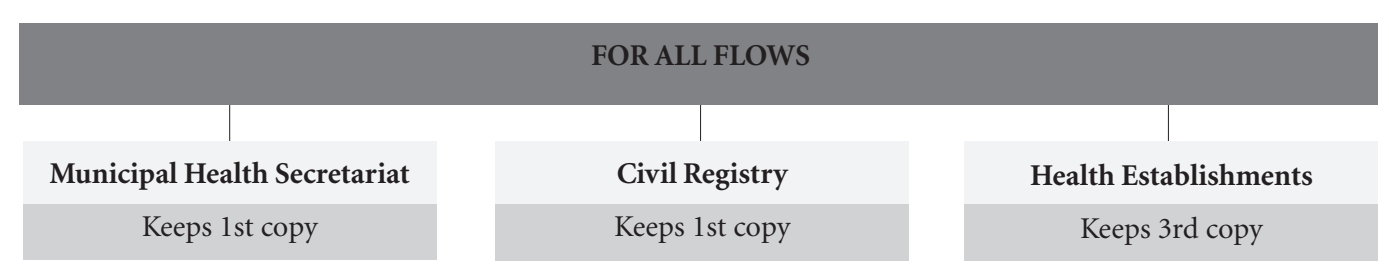

Figure 2. Flows of the DNV in accordance with Articles 30 to 33 of Ordinance 116 MS/SVS 11/02/09.

Source: SINASC. Percentages represent the incompleteness attributed to each municipality in the Alto do Juruá region.

A DNV can contain as many as four flows, depending on the characteristics of the region where the delivery occurred ${ }^{1}$ and the professionals should fill three copies (white, yellow and 
pink), in accordance with Articles 30 to 33 of Ordinance No 116 -MS/SVS of $11 / 02 / 2009^{14}$. In the Alto do Juruá region, all the municipalities are separated from each other by waterways, a fact that makes it difficult for the population to access the urban centers. Also, there are still numerous indigenous communities and a strong culture of delivering babies at home. All these characteristics justify the use of the four flows of the DNV in this region (Figure 1). This task is often delegated to the technical-administrative personnel of the health establishment ${ }^{18}$, or to professionals who are not familiar with the medical terminology or who have restricted access to the medical records ${ }^{2}$. In addition, it is assumed that variables are left blank as a result of lack of attention or lack of commitment by the professional responsible for the DNV when filling the form ${ }^{11}$. Those variables recorded as "ignored" are usually consequences of several deficiencies (e.g. lack of information in the records) $)^{19}$. Other difficulties arise due to a lack of understanding on how to fill this form and a lack of methodological clarity in the DNV manual ${ }^{11}$. One should also consider the fact that the mother or her partner may not know, or simply refuse, to provide information. Some studies suggest awareness ${ }^{5}$ and professional training $^{11,17-21}$ as tools to improve the quality of completion of this document, plus an active follow-up and feedback in places where the form is filled in order to correct the data collected ${ }^{20}$.

The quality of the information provided and whether it reflects the real conditions of a local context - to avoid wrong conclusions - are the main concerns with regard to an information system and are crucial for those who will use the data available ${ }^{19}$. Thus, the correct and complete filling of the DNV is essential for the quality and reliability of the information collected by the system.

There are several methodologies to analyze and estimate the SINASC coverage. These include comparison with data from the Civil Registry; comparison with the number of live births estimated by the IBGE through demographic projections; the use of active search methods for the DNV in hospitals, notaries, other healthcare facilities and home visits; and even the use of the Information System for Primary Care (SIAB) in municipalities with good coverage of the Family Health Program ${ }^{10}$. The comparison with data from the Civil Registry of the IBGE was selected due to the impossibility of performing an active search and because there is no data from demographic projections by municipality that allowed the method used by the Interagency Network for Health Information (RIPSA). It is known that the Civil Registry is traditionally the most important source for obtaining data on the number of births in the country, but there are doubts with regard to the reliability of the information the total coverage of the events ${ }^{8}$.

It is known that one of the purposes of the SINASC was to address the shortcomings of the Civil Registry, where it is hoped that the number of live births in the SINASC was equal or superior to registry ${ }^{10}$. We would expect that the number of live births recorded in the SINASC would always be superior to that recorded in the Civil Registry. This is due to the high proportion of underreporting, since there is a significant proportion of births that are never recorded ${ }^{9}$. Another limiting factor is the existence of a considerable number of births that are recorded in later years (late birth registration), making the registration of births in one year incongruous with the total births in that particular year ${ }^{8}$.

The methodological approach adopted in this study follows the pattern of other studies that addressed the incompleteness of the SINASC data ${ }^{5,7,10,17,19,22-24}$, by using "blank" and "ignored' variables as an analysis starting-point. If the trend revealed in those other studies was maintained, we would be expected to report a decrease in the amount of not declared information. Studies conducted in the Northeast region $^{19,24}$, Southeast region ${ }^{7,18,22}$ and South region $^{5,25}$, as well nation-wide studies ${ }^{10,17}$, showed that there is a significant improvement in the SINASC, especially with regard to the incompleteness of the data. However, this is not what we have observed for the Alto do Juruá region in the State of Acre, when comparing the years of 2005 and 2010. Out of the 15 variables studied, 11 showed increased incompleteness, especially the variables regarding the newborn, namely race/colour, Apgar score at 1 minute, Apgar score at 5 minutes and weight. The variable occupation of the mother also showed a significant increase of underreporting, which is in agreement with the published data.

Mello Jorge et al. ${ }^{11}$ stated that when considering only the live births registered in one year, the SINASC data is always higher. They say that because from 1998 to 2004 the coverage of the SINASC was at least $90 \%$ of that registered in the notaries ${ }^{11}$. This was not observed in our study, in which there was a significant decrease in coverage from 2005 to 2010, mainly in the Jurua region and in the State of Acre as a whole. Many issues 
are raised to justify or explain this fact, like the discontinuity of awareness raising and training of professionals, both for those responsible for fill the DNV and those that feed the system; the high turnover and/or hiring of new personnel, as well as the diversity of professionals that fill the DNV; devaluation of the document as important for the formulation of health statistics; lack of incentives; and public policies and supervision by managers, among many others. Despite the many justifications, solutions and interventions to reverse this situation are needed.

\section{Final considerations}

The decrease in quality concerning the two parameters used in this study, incompleteness and coverage, shows that the SINASC needs much more investment and incentives. This is the first study that evaluated municipalities in the northern region of Brazil. It is believed that this work provides information to improve the quality of the SINASC data and also serves to stimulate research in the region.

There is no doubt that the SINASC is one of the most important health databases in Brazil, but it is not without flaws. Quality assessment is needed to identify both its strengths and weaknesses, so that its information can be more reliable, complete and with good coverage. This will allow for the monitoring of maternal and child health as well as provide a better standpoint from where to elaborate public policies.

So, it is necessary to routinely invest on capacity building of professionals responsible for filling the DNV. Also supervision to increase interest and commitment in producing reliable information for the construction of information systems able to that support intervention policies is crucial.

\section{Collaborations}

JG Dombrowski, R Ataíde and RM Souza participated in the planning of the study, data collection, statistical analysis, interpretation of results, drafting of the article and design and final text. JG Dombrowski coordinated the analyses and prepared all drafts of the paper, incorporating comments by coauthors. P Marchesini and CRF Marinho participated in the planning of the study, interpretation of results, and design and final text.

\section{Acknowledgments}

This work was supported by Fundação de Amparo à Pesquisa do Estado de São Paulo (Fapesp), Coordenação de Aperfeiçoamento de Pessoal de Nível Superior (Capes) and Conselho Nacional de Desenvolvimento Científico e Tecnológico (CNPq). 
References

1. Brasil. Ministério da Saúde (MS). Manual de Instruções para o preenchimento da Declaração de Nascido Vivo. $4^{\mathrm{a}}$ Ed. Brasília: MS; 2010.

2. Luquetti DV, Koifman RJ. Qualidade da notificação de anomalias congênitas pelo Sistema de Informações sobre Nascidos Vivos (SINASC): estudo comparativo nos anos 2004 e 2007. Cad Saude Publica 2010; 26(9):17561765.

3. Brasil. Ministério da Saúde (MS). Manual de Procedimentos do Sistema de Informações sobre Nascidos Vivos. Brasília: MS; 2001.

4. Silva GF, Aidar T, Mathias TAF. Qualidade do Sistema de Informações de Nascidos Vivos no Estado do Paraná, 2000 a 2005. Rev Esc Enfermagem-USP 2011; 45(1):79-86.

5. Silveira MF, Santos IS, Matijasevich A, Malta DC, Duarte EC. Nascimentos pré-termo no Brasil entre 1994 e 2005 conforme o Sistema de Informações sobre Nascidos Vivos (SINASC). Cad Saude Publica 2009; 25(6):1267-1275.

6. Frias PG, Pereira PMH, Andrade CLT, Lira PIC, Szwarcwald CL. Avaliação da adequação das informações de mortalidade e nascidos vivos no Estado de Pernambuco, Brasil. Cad Saude Publica 2010; 26(4):671-681.

7. Guimarães EAA, Loyola Filho AI, Hartz ZMA, Meira AJ, Luz ZMP. A descentralização do SINASC e a completitude das variáveis da declaração de nascido vivo em municípios mineiros de 1998 a 2005. Rev Bras

8. Crescimento Desenvolv Hum 2011; 21(3):832-840. Mello Jorge MHP, Gotlieb SLD, Soboll MLMS, Almeida MF, Latorre MRDO. Avaliação do Sistema de Informação sobre Nascidos Vivos e o uso de seus dados em epidemiologia e estatística de saúde. Rev Saude Publica 1993; 27(Supl. 6):1-46.

9. Barbosa L. Avaliação da qualidade das informações sobre fecundidade provenientes do SINASC no Nordeste, 2000. Rev Bras Est Pop 2005; 22(1):141-158.

10. Theme Filha MM, Gama SGN, Cunha CB, Leal MC. Confiabilidade do Sistema de Informações sobre Nascidos Vivos Hospitalares no Município do Rio de Janeiro, 1999-2001. Cad Saude Publica 2004; 20(1):1999-2001.

11. Mello Jorge MHP, Laurenti R, Gotlieb SLD. Análise da qualidade das estatísticas vitais brasileiras: a experiência de implantação do SIM e do SINASC. Cien Saude Colet 2007; 12(3):643-654.

12. Pedraza DF. Qualidade do Sistema de Informações sobre Nascidos Vivos (Sinasc): análise crítica da literatura. Cien Saude Colet 2012; 17(10):2729-2737.

13. Paiva NS, Coeli CM, Moreno AB, Guimarães RM, Camargo Júnior KR. Sistema de informações sobre nascidos vivos: um estudo de revisão. Cien Saude Colet 2011; 16(1):1211-1220.

14. Brasil. Ministério da Saúde (MS). Portaria no 116, de 11 de fevereiro de 2009. Regulamentando a coleta de dados, fluxo e periodicidade do envio de informações sobre óbitos e nascidos vivos, para os Sistemas de Informações em Saúde. Diário Oficial da União 2009; 30 out.
15. Brasil. Ministério da Saúde (MS). Departamento de Informática do SUS (Datasus). Sistema de Informações sobre Nascidos Vivos (SINASC). [cited 2013 Jan 25]. Available from: http://www.datasus.gov.br

16. Instituto Brasileiro de Geografia e Estatística (IBGE). Sistema de Informações sobre Nascidos Vivos (SINASC). [cited 2013 Jan 30]. Available from: http://www.ibge. gov.br

17. Romero DE, Cunha CB. Avaliação da qualidade das variáveis epidemiológicas e demográficas do Sistema de Informações sobre Nascidos Vivos, 2002. Cad Saude Publica 2007; 23(3):701-714.

18. Nhoncanse GC, Melo DG. Confiabilidade da Declaração de Nascido Vivo como fonte de informação sobre os defeitos congênitos no Município de São Carlos, São Paulo, Brasil. Cien Saude Colet 2012; 17(4):955-963.

19. Costa JMB da S, Frias PG. Avaliação da completitude das variáveis da Declaração de Nascido Vivo de residentes em Pernambuco, Brasil, 1996 a 2005. Cad Saude Publica 2009; 25(3):613-624.

20. Ferreira JSA, Vilela MBR, Aragão PS, Oliveira RA, Tiné RF. Avaliação da qualidade da informação: linkage entre SIM e SINASC em Jaboatão dos Guararapes (PE). Cien Saude Colet 2011; 16(1):1241-1246.

21. Silva CF, Leite ÁJM, Almeida NMGS. Linkage entre bancos de dados de nascidos vivos e óbitos infantis em município do Nordeste do Brasil: qualidade dos sistemas de informação. Cad Saude Publica 2009; 25(7):1552-1558.

22. Almeida M, Alencar G, França Jr I, Novaes H, Siqueira A, Schoeps D, Campbell O, Rodrigues LC. Validade das informações das declarações de nascidos vivos com base em estudo de caso-controle. Cad Saude Publica 2006; 22(3):643-652.

23. Paes NA, Santos CSA. As estatísticas de nascimento e os fatores maternos e da criança nas microrregiões do Nordeste brasileiro: uma investigação usando análise fatorial. Cad Saude Publica 2010; 26(2):311-322.

24. Mascarenhas MDM, Gomes KRO. Confiabilidade dos dados do Sistema de Informações sobre Nascidos Vivos em Teresina, Estado do Piaú́, Brasil - 2002. Cien Saude Colet 2011; 16(1):1233-1239.

25. Predebon KM, Mathias TAF, Aidar T, Rodrigues AL. Desigualdade sócio-espacial expressa por indicadores do Sistema de Informações sobre Nascidos Vivos (SINASC). Cad Saude Publica 2010; 26(8):1583-1594.

Article submitted on 04/08/2014

Approved on 16/09/2014

Final version submitted on 23/09/2014 